\title{
Tumor volume: a new prognostic factor of oncological outcome of localized clear cell renal cell carcinoma
}

Shao-Hao Chen ${ }^{\dagger}$, Long-Yao Xu ${ }^{\dagger}$, Yu-Peng $\mathrm{Wu}^{\dagger}$, Zhi-Bin Ke${ }^{\dagger}$, Peng Huang, Fei Lin, Xiao-Dong Li, Xue-Yi Xue, Yong Wei, Qing-Shui Zheng ${ }^{*}$ and Ning $X^{*}{ }^{*}$ (D)

\begin{abstract}
Background: Clear cell renal cell carcinoma (ccRCC) is one of the most frequent malignancies; however, the present prognostic factors was deficient. This study aims to explore whether there is a relationship between tumor volume (TV) and oncological outcomes for localized ccRCC.

Methods: Seven hundred forty-nine localized ccRCC patients underwent surgery in our hospital. TV was outlined and calculated using a three-dimensional conformal radiotherapy planning system. We used receiver operating characteristic (ROC) curves to identified optimal cut-off value. Univariable and multivariable Cox regression models were performed to explore the association between TV and oncological outcomes. KaplanMeier method and log-rank test were used to estimate survival probabilities and determine the significance, respectively. Time-dependent ROC curve was utilized to assess the prognostic effect.

Results: Log rank test showed that higher Fuhrman grade, advanced pT classification and higher TV were associated with shortened OS, cancer-specific survival (CSS), freedom from metastasis (FFM) and freedom from local recurrence (FFLR). multivariable analysis showed higher Fuhrman grade and higher TV were predictors of adverse OS and CSS. The AUC of TV for FFLR was 0.822. The AUC of TV (0.864) for FFM was higher than that of pT classification (0.818) and Fuhrman grade (0.803). For OS and CSS, the AUC of TV was higher than that of Fuhrman grade (0.832 vs. $0.799 ; 0.829$ vs 0.790$)$.

Conclusions: High TV was an independent predictor of poor CSS, OS, FFLR and FFM of localized cCRCC. Compared with pT classification and Fuhrman grade, TV could be a new and better prognostic factor of oncological outcome of localized $\mathrm{CCRCC}$, which might contribute to tailored follow-up or management strategies.
\end{abstract}

Keywords: Tumor volume, Oncological outcome, Prognostic factor, Survival, Localized clear cell renal cell carcinoma

\footnotetext{
* Correspondence: zhengqingshui@fjmu.edu.cn; drxun@fjmu.edu.cn

'Shao-Hao Chen, Long-Yao Xu, Yu-Peng Wu and Zhi-Bin Ke contributed

equally to this work and should be considered co-first authors.

Department of Urology, the First Affiliated Hospital of Fujian Medical

University, 20 Chazhong Road, Fuzhou 350005, China
}

(c) The Author(s). 2021 Open Access This article is licensed under a Creative Commons Attribution 4.0 International License, which permits use, sharing, adaptation, distribution and reproduction in any medium or format, as long as you give appropriate credit to the original author(s) and the source, provide a link to the Creative Commons licence, and indicate if changes were made. The images or other third party material in this article are included in the article's Creative Commons licence, unless indicated otherwise in a credit line to the material. If material is not included in the article's Creative Commons licence and your intended use is not permitted by statutory regulation or exceeds the permitted use, you will need to obtain permission directly from the copyright holder. To view a copy of this licence, visit http://creativecommons.org/licenses/by/4.0/ The Creative Commons Public Domain Dedication waiver (http://creativecommons.org/publicdomain/zero/1.0/) applies to the data made available in this article, unless otherwise stated in a credit line to the data. 


\section{Background}

As one of the most frequent malignancies, renal cell carcinoma (RCC) accounted for approximately $2-3 \%$ of all cancers [1, 2]. There were $80-90 \%$ of clear cell RCC (ccRCC), which is the major histological subtype of RCC $[3,4]$. Metastases occurred in about $25-30 \%$ of patients with ccRCC at first diagnosis; besides, $20-30 \%$ of localized RCC patients have metastases after treatment [5]. Hence, there is an urgent need to identify prognostic parameters predicting recurrence or metastasis.

Although Fuhrman nuclear grading [6] and TNM systems [7] are useful prognostic parameters, they are still not perfect [8]. Klatte et al. [8]. reported that Fuhrman nuclear grading system have been shown to be suboptimal due to its inter- observer and intraobserver variability. $\mathrm{T}$ staging is based on the maximum diameter of solid tumors such as RCC [9] and hepatocellular carcinoma [10]; however, tumor diameter could not be fully representative of tumor volume (TV). Other well-known prognostic parameters included tumor necrosis [11], warm ischemia time, multifocality [12], bilateral occurrence of carcinoma [13], sarcomatoid and rhabdoid features [14], vascular and lymphatic microfiltration [15], caval or renal thrombosis [16]; however, they were deficient. The insufficiency of present prognostic factors has resulted in consideration of new factors. TV is more representative of tumor burden compared with diameter. There is accumulating evidence that the measurement of TV is applied to the evaluation of renal function [17-20], but only a few report on the relationship between oncological outcomes and TV of ccRCC [21].

The objective of our study was to evaluate TV, clinicopathological features and oncological outcomes of localized ccRCC, to determine whether TV is a prognostic factor for cancer-specific survival (CSS), overall survival (OS), local recurrence and distant metastases of ccRCC.

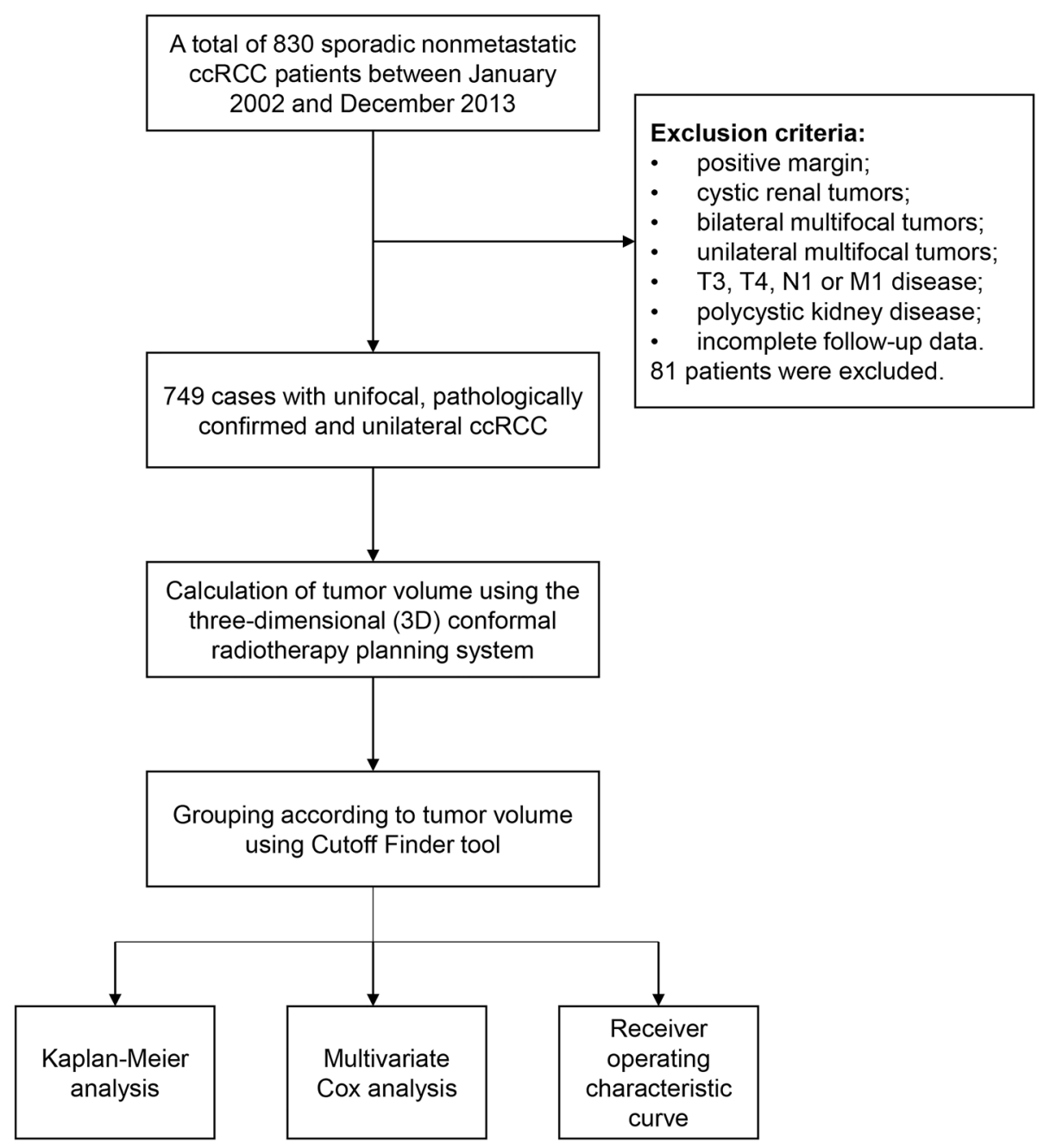

Fig. 1 The flow chart of this study 
Table 1 Patients and tumors characteristics

\begin{tabular}{|c|c|}
\hline Variable & $\begin{array}{l}\text { Mean } \pm \text { SD or median } \\
\text { (interquartile range) or } n(\%)\end{array}$ \\
\hline Age, year & $54.72 \pm 11.48$ \\
\hline Tumor diameter, cm & $5.94 \pm 3.06$ \\
\hline \multicolumn{2}{|l|}{ Gender } \\
\hline Male & $505(67.4)$ \\
\hline Female & $244(32.6)$ \\
\hline \multicolumn{2}{|l|}{ Tumor location } \\
\hline Left kidney & $366(48.9)$ \\
\hline Right kidney & $383(51.1)$ \\
\hline \multicolumn{2}{|l|}{ Hypertension } \\
\hline No & $488(65.2)$ \\
\hline Yes & $261(34.8)$ \\
\hline \multicolumn{2}{|l|}{ Diabetes } \\
\hline No & $640(85.4)$ \\
\hline Yes & 109 (14.6) \\
\hline \multicolumn{2}{|l|}{ Smoking history } \\
\hline No & $430(57.4)$ \\
\hline Yes & 319 (42.6) \\
\hline \multicolumn{2}{|l|}{ BMI } \\
\hline$<25$ & $507(67.7)$ \\
\hline$\geq 25$ & $242(32.3)$ \\
\hline \multicolumn{2}{|l|}{ Sugical approach } \\
\hline Open & $321(42.9)$ \\
\hline Laparoscopic & $428(57.1)$ \\
\hline \multicolumn{2}{|l|}{ Surgical modality } \\
\hline Partial nephrectomy & $317(42.3)$ \\
\hline Radical nephrectomy & $432(57.7)$ \\
\hline \multicolumn{2}{|l|}{ Tumor necrosis extent } \\
\hline $\mathrm{TN}=0 \%$ & $628(83.8)$ \\
\hline $0 \%<\mathrm{TN}<20 \%$ & 57 (7.6) \\
\hline $\mathrm{TN} \geq 20 \%$ & $64(8.5)$ \\
\hline \multicolumn{2}{|l|}{ Ki-67 index } \\
\hline $\mathrm{Ki}-67=0 \%$ & 639 (85.3) \\
\hline $0 \%<\mathrm{Ki}-67<10 \%$ & $66(8.8)$ \\
\hline $\mathrm{Ki}-67 \geq 10 \%$ & $44(5.9)$ \\
\hline \multicolumn{2}{|l|}{ Fuhrman grade } \\
\hline I & 239 (31.9) \\
\hline$\|$ & $324(43.3)$ \\
\hline III & $140(18.7)$ \\
\hline IV & $46(6.1)$ \\
\hline \multicolumn{2}{|l|}{ pT classification } \\
\hline $1 \mathrm{a}$ & 229 (30.6) \\
\hline $1 b$ & $270(36.0)$ \\
\hline $2 a$ & $130(17.4)$ \\
\hline
\end{tabular}

Table 1 Patients and tumors characteristics (Continued)

\begin{tabular}{|c|c|}
\hline Variable & $\begin{array}{l}\text { Mean } \pm \text { SD or median } \\
\text { (interquartile range) or } n(\%)\end{array}$ \\
\hline $2 b$ & $120(16.0)$ \\
\hline \multicolumn{2}{|l|}{ Tumor volume group } \\
\hline$V<17 \mathrm{~cm}^{3}$ & $267(35.6)$ \\
\hline $17 \mathrm{~cm}^{3} \leq \mathrm{V}<40 \mathrm{~cm}^{3}$ & $172(23.0)$ \\
\hline $40 \mathrm{~cm}^{3} \leq \mathrm{V}<134 \mathrm{~cm}^{3}$ & $156(20.8)$ \\
\hline$V \geq 134 \mathrm{~cm}^{3}$ & $154(20.6)$ \\
\hline Median follow-up, mth & $118.0(85-155)$ \\
\hline Local relapse & $69(9.2)$ \\
\hline Metastatic progression & $128(17.1)$ \\
\hline Death from cancer & $196(26.2)$ \\
\hline Death & $261(34.8)$ \\
\hline
\end{tabular}

Abbreviations: BMI Body mass index

\section{Methods}

\section{Study population}

The flow chart of this study is shown in Fig. 1. A total of 830 sporadic nonmetastatic ccRCC patients between January 2002 and December 2013 in our hospital were identified. All these patients underwent partial or radical nephrectomy. Only unifocal, pathologically confirmed and unilateral ccRCCs were included. We excluded patients with cystic renal tumors, bilateral multifocal tumors, unilateral multifocal tumors, patients with T3, T4, N1 or M1 disease, positive margin and also polycystic kidney disease. The symptomatic group included patients with abdominal masses, flank abdominal pain or hematuria while those who discovered only by computed tomography (CT), ultrasound, or magnetic resonance imaging were classified as the asymptomatic group. Clinicopathologic data such as age, gender, tumor diameter, tumor location, Fuhrman grade and TV were collected (Table 1).

\section{Outline and calculation of TV}

The specific location, length and degree of invasion of ccRCC were determined by comprehensive analysis of preoperative CT images. Preoperative enhanced CT images were transmitted in digital format to the threedimensional (3D) conformal radiotherapy planning system. Tumor contours of all cases were outlined by two experienced attendings in our center using the 3D conformal radiotherapy planning system, and TV was automatically calculated. Disagreements between the two attendings were settled by a third urologist (Fig. 2).

\section{Statistical analysis}

Demographic features of patients and radiographic and pathological characteristics of renal masses were summarized. Baseline characteristics are presented using standard descriptive statistics: means \pm standard deviations (SDs) 


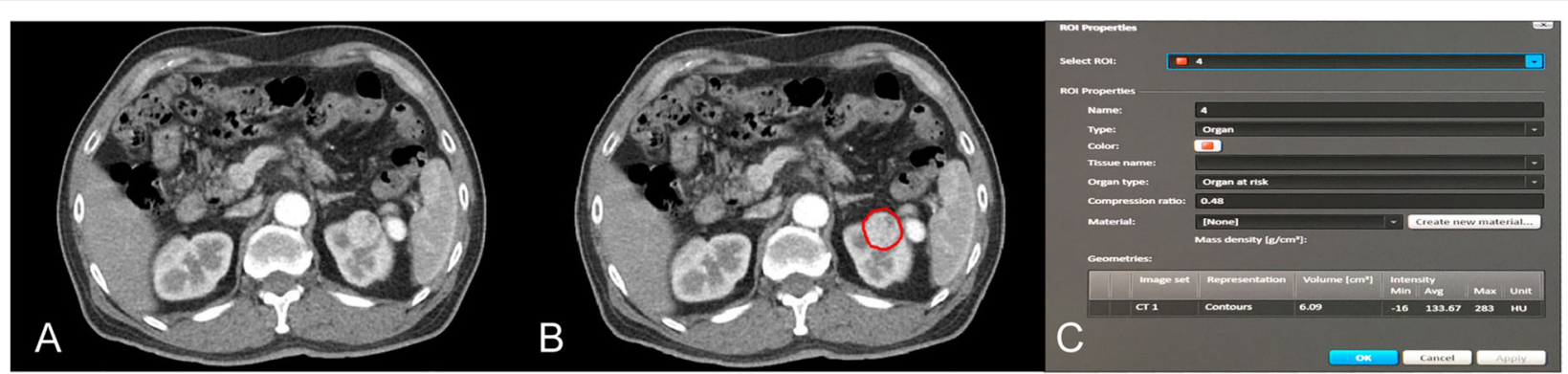

Fig. 2 a Unmarked image; b Tumor contours were outlined; c After tumor contours were marked, tumor volume was automatically calculated by the $3 \mathrm{D}$ conformal radiotherapy planning system

for continuous variables with normal distribution; median (interquartile range) for continuous variables with nonnormal distribution means; number (percentage) for categorical variables. Data analysis was conducted by using SPSS 19.0 (SPSS Inc., Chicago, IL, USA). Chi-square test was used to analyze qualitative variables while continuous variables were compared using Student's t test. The mean values between groups were analyzed using analysis of variance, and the correlation between variables was tested by Spearman correlation analysis. The consistency test was used to evaluate the consistency on the 3D calculation of tumor volume between the two experienced attendings.
The optimal cut-off level of TV for overall survival (OS) was determined using the web services-based Cutoff Finder (http://molpath.charite.de/cutoff/) [22]. There were a total of five methods for cutoff optimization in Cutoff Finder. The first method is based merely on the distribution of biomarker. Methods 2-4 deal with optimization of the correlation with a binary variable. Method 5 is used to optimize the correlation with survival variables. In this study, data containing information of TV, overall survival and survival status were uploaded and TV was assigned as biomarker. ROC curve was chosen as method and Waterfall plot was used to show the correct classification of the
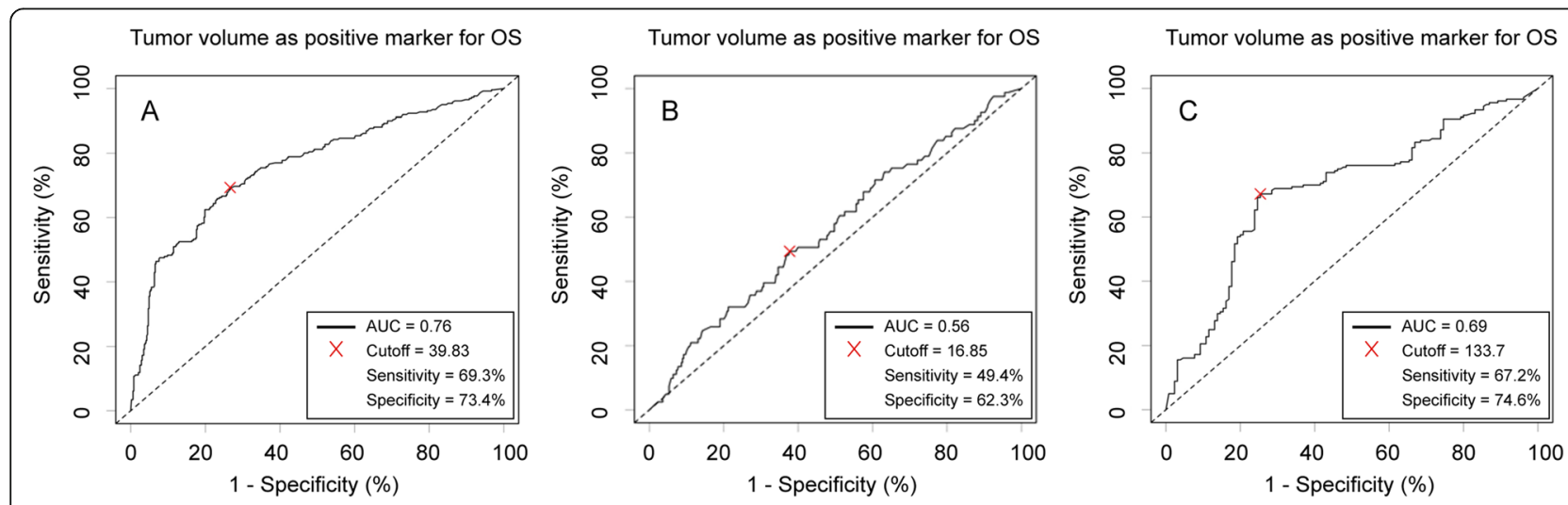

D
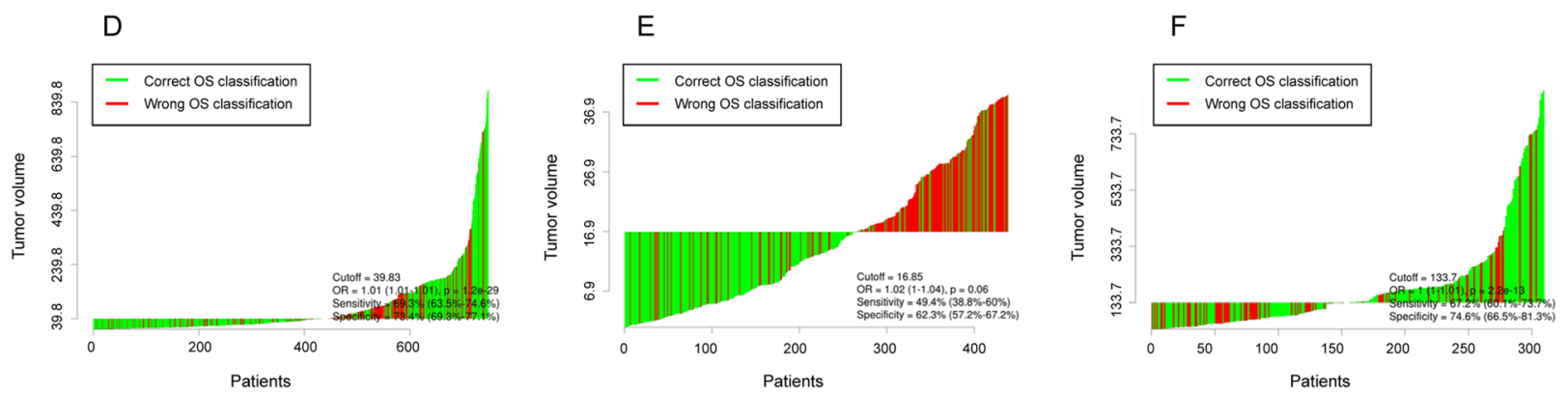

Fig. 3 The ROC curves $(\mathbf{a}, \mathbf{b}, \mathbf{c})$ and Waterfall plots $(\mathbf{d}, \mathbf{e}, \mathbf{f})$ are presented. Three cutoffs were selected as 17, 40 and 134, which approximated to 16.85, 39.83 and 133.7, respectively. Tumor volume was graded as group $1\left(V<17 \mathrm{~cm}^{3}\right)$, group $2\left(17 \leq V<40 \mathrm{~cm}^{3}\right)$, group $3\left(40 \leq V<134 \mathrm{~cm}^{3}\right)$ and group $4\left(\mathrm{~V} \geq 134 \mathrm{~cm}^{3}\right)$ 

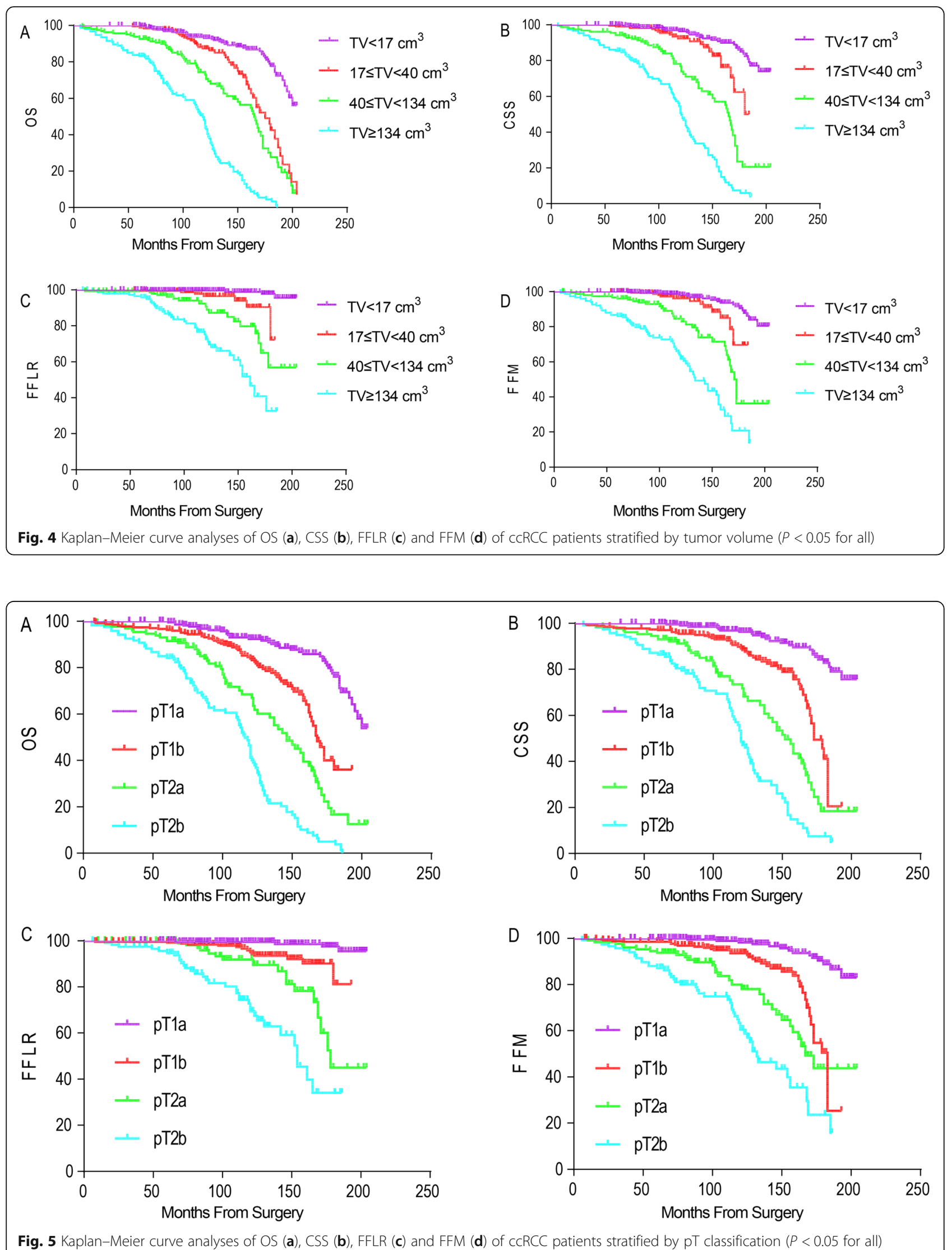
grouping. Univariable and multivariable regression models were used to explore the association between TV and oncological outcomes and clinicopathological data. Kaplan-Meier analysis was used to estimate the survival probabilities and log-rank test was used to determine the significance of OS, CSS, FFM and FFLR of localized ccRCC among various TV, Fuhrman grade and pT classification. Further, to estimate the accuracy of prognostic factors, we used receiver operating characteristic (ROC) curves to assess the prognostic effect of each risk factor for oncological outcome over 5 year with binomial estimation of confidence intervals $(\mathrm{CI})$ of the area under the curve (AUC). We considered $P<0.05$ as statistical significance.

\section{Results}

\section{Patients and tumor characteristics}

Sixty patients without complete CT/CT angiography data and 21 patients with incomplete follow-up were excluded. This left a final cohort of 749 ccRCC patients with CT/CT angiography data who underwent partial or radical nephrectomy at our center. There were 505 (67.4\%) men. Mean age of all patients was $54.72(18-72)$ years. Mean tumor diameter was $5.94(0.60-14.10) \mathrm{cm}$. Partial nephrectomy (PN) was performed in 317 (42.3\%) cases. The consistency test demonstrated that Kappa value was 0.910 and $P$ value $<0.05$, indicating that there was an excellent consistency on the 3D calculation of tumor volume between the two experienced attendings.

The optimal cutoff level of TV for OS was determined by using ROC analysis, and the ROC curves and Waterfall plots are presented in Fig. 3. Firstly, the Cutoff Finder identified the optimal cut-off value as $40 \mathrm{~cm}^{3}$ and we classified patients into two groups according to the tumor volume of $40 \mathrm{~cm}^{3}$. Next, we further classified each of them into two groups and the Cutoff Finder identified the optimal cut-off value as $17 \mathrm{~cm}^{3}$ and $134 \mathrm{~cm}^{3}$, respectively. TV was graded as group $1\left(\mathrm{TV}<17 \mathrm{~cm}^{3}\right)$, group $2\left(17 \leq \mathrm{TV}<40 \mathrm{~cm}^{3}\right)$, group $3\left(40 \leq \mathrm{TV}<134 \mathrm{~cm}^{3}\right)$, and group $4\left(\mathrm{TV} \geq 134 \mathrm{~cm}^{3}\right)$ and there were $267(35.6 \%)$, 172 (23.0\%), $156(20.8 \%)$, and $154(20.6 \%)$ patients in each group, respectively. Patients and tumors characteristics are presented in Table 1.

\section{Oncological outcomes}

During follow-up, there were 65 deaths independent of RCC and 196 from RCC. There were 69 patients with local recurrence and 128 had metastatic progression. The OS of all patients at 5 and 10 years postoperatively were $94.6 \%$ [95\% confidence interval (CI), 93.0-96.2\%] and $77.1 \%$ (95\% CI, 73.8-80.4\%), respectively. Log rank test revealed that high TV, high Fuhrman grade and advanced $\mathrm{pT}$ classification were associated with poor OS, CSS, FFLR and FFM of patients after surgery $(P<0.001$ for all) (Figs. 4, 5, 6).
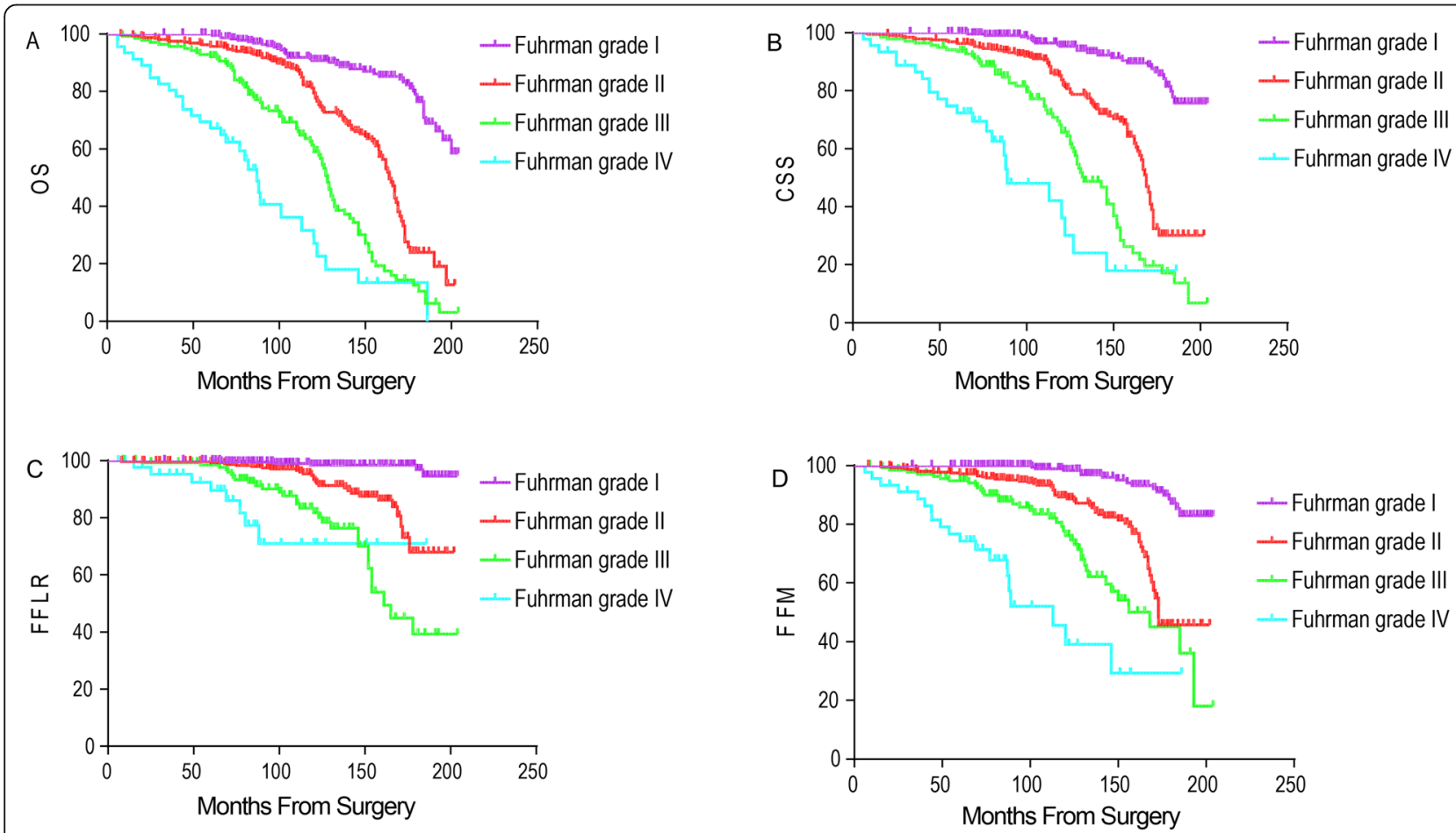

Fig. 6 Kaplan-Meier curve analyses of OS (a), CSS (b), FFLR (c) and FFM (d) of ccRCC patients stratified by Fuhrman grade $(P<0.05$ for all) 
Univariable Cox proportional hazards analysis showed that high Fuhrman grade, high TV and advanced pT classification were all associated with poor OS, CSS, FFLR and FFM of localized ccRCC after surgery, but tumor necrosis and Ki-67 did not predict the oncological outcome independently $(P<0.05$ for all; Tables $2,3,4$ and 5). In multivariable analysis, Fuhrman grade and TV has significant association with OS and CSS $(P<0.05$ for all; Tables 2 and 3). Correlation between TV and FFLR was significant in the multivariable model $(P<0.05$, Table 4), although univariable analysis showed that Fuhrman grade, pT classification and TV were all associated with FFLR of localized ccRCC after surgery. Multivariable analysis of the whole cohort of patients indicated that $\mathrm{pT}$ classification, TV and Fuhrman grade of ccRCC, has significant association with FFM $(P<0.05$ for all, Table 5). The Cox model have been evaluated by the concordance index and have values of 0.78 , suggesting relatively similar performance by utilizing $R$ packages.

The AUC of Fuhrman grade, pT classification and TV were compared for prognosis of localized ccRCC at 5 year postoperatively. For 5-year OS and CSS, the AUC of TV was higher than that of Fuhrman grade (0.832, 95\%CI:0.787-0.876 vs. 0.799 , 95\%CI:0.735-0.864 and $0.829,95 \%$ CI:0.780-0.879 vs $0.790,95 \%$ CI:0.719-0.862, respectively) (Fig. 7a, b). The AUC of TV was 0.822 (95\%CI:0.710-0.933) for prognosis of 5-year FFLR (Fig. 7c). The AUC of TV $(0.864,95 \% \mathrm{CI}: 0.823-0.906)$ for 5year FFM was higher than that of Fuhrman grade $(0.803$, 95\%CI:0.726-0.881) and pT classification $(0.818,95 \% \mathrm{CI}$ : 0.754-0.881) (Fig. 7d).

Table 2 Cox regression analysis of predicting factors for overall survival in 749 patients with localized clear cell renal cell carcinoma

\begin{tabular}{|c|c|c|c|c|}
\hline \multirow[t]{2}{*}{ Variable } & \multicolumn{2}{|l|}{ Univariate analysis } & \multicolumn{2}{|c|}{ Multivariate analysis } \\
\hline & HR $(95 \% \mathrm{Cl})$ & $P$ value & $\mathrm{HR}(95 \% \mathrm{Cl})$ & $P$ value \\
\hline pT classification & & $<0.001$ & & 0.123 \\
\hline (T1b vs. T1a) & $2.79(1.86-4.19)$ & $<0.001$ & $1.08(0.66-1.87)$ & 0.401 \\
\hline (T2a vs. T1a) & $5.56(3.70-8.36)$ & $<0.001$ & $1.24(0.86-3.82)$ & 0.525 \\
\hline (T2b vs. T1a) & $12.92(8.79-18.99)$ & $<0.001$ & $2.45(0.96-4.19)$ & 0.442 \\
\hline Age $(\geq 65$ vs < 65) & $0.93(0.70-1.23)$ & 0.927 & $0.82(0.64-1.12)$ & 0.658 \\
\hline Gender & $0.89(0.69-1.15)$ & 0.362 & & \\
\hline Fuhrman grade & & $<0.001$ & & 0.001 \\
\hline (II vs. I) & $3.62(2.50-5.25)$ & $<0.001$ & $1.21(0.70-2.09)$ & 0.494 \\
\hline (III vs. I) & $8.17(5.57-11.98)$ & $<0.001$ & $1.60(0.88-2.91)$ & 0.123 \\
\hline (IV vs. I) & $18.08(11.12-29.40)$ & $<0.001$ & $3.10(1.57-6.12)$ & 0.001 \\
\hline Smoking history & $1.10(0.86-1.40)$ & 0.449 & & \\
\hline Hypertension & $1.01(0.78-1.29)$ & 0.970 & & \\
\hline Diabetes & $1.04(0.74-1.47)$ & 0.819 & & \\
\hline Tumor necrosis extent & & 0.651 & & \\
\hline $0 \%<\mathrm{TN}<20 \%$ vs. TN $=0 \%$ & $0.86(0.51-1.45)$ & 0.560 & & \\
\hline $\mathrm{TN} \geq 20 \%$ vs. TN $=0 \%$ & $1.15(0.77-1.73)$ & 0.504 & & \\
\hline Ki-67 index & - & 0.507 & & \\
\hline $0 \%<$ Ki-67 < 10\%vs. Ki-67 =0\% & $1.13(0.76-1.68)$ & 0.537 & & \\
\hline Ki- $67 \geq 10 \%$ vs. Ki- $67=0 \%$ & $1.29(0.80-2.09)$ & 0.296 & & \\
\hline Tumor volume group & & $<0.001$ & & $<0.001$ \\
\hline $17 \mathrm{~cm}^{3} \leq V<40 \mathrm{~cm}^{3}$ vs. $V<17 \mathrm{~cm}^{3}$ & $2.96(1.88-4.65)$ & $<0.001$ & $2.66(1.54-4.60)$ & $<0.001$ \\
\hline $40 \mathrm{~cm}^{3} \leq V<134 \mathrm{~cm}^{3}$ vs $V<17 \mathrm{~cm}^{3}$ & $5.08(3.39-7.60)$ & $<0.001$ & $4.25(2.39-7.58)$ & $<0.001$ \\
\hline$V \geq 134 \mathrm{~cm}^{3}$ vs $V<17 \mathrm{~cm}^{3}$ & $14.19(9.80-20.56)$ & $<0.001$ & $9.02(5.06-16.08)$ & $<0.001$ \\
\hline $\mathrm{BMI}(\geq 25$ vs $<25)$ & $0.93(0.72-1.21)$ & 0.589 & & \\
\hline Sugical approach (open vs laparoscopic) & $0.945(0.74-1.21)$ & 0.665 & & \\
\hline Surgical modality (partial vs radical nephrectomy) & $1.25(0.97-1.60)$ & 0.081 & & \\
\hline Tumor location (left vs right kidney) & $0.79(0.62-1.00)$ & 0.053 & & \\
\hline
\end{tabular}


Table 3 Cox regression analysis of predicting factors for cancer-specifc survival in 749 patients with localized clear cell renal cell carcinoma

\begin{tabular}{|c|c|c|c|c|}
\hline \multirow[t]{2}{*}{ Variable } & \multicolumn{2}{|l|}{ Univariate analysis } & \multicolumn{2}{|c|}{ Multivariate analysis } \\
\hline & HR (95\% CI) & $P$ value & HR (95\% Cl) & $P$ value \\
\hline pT classification & & $<0.001$ & & 0.264 \\
\hline (T1b vs. T1a) & $3.31(2.00-5.47)$ & $<0.001$ & $1.02(0.86-1.52)$ & 0.093 \\
\hline (T2a vs. T1a) & $8.18(4.99-13.42)$ & $<0.001$ & $2.11(0.89-4.07)$ & 0.670 \\
\hline (T2b vs. T1a) & $16.75(10.40-26.97)$ & $<0.001$ & $2.87(0.97-4.73)$ & 0.344 \\
\hline Age $(\geq 65$ vs <65) & $0.95(0.69-1.32)$ & 0.757 & $0.86(0.61-1.25)$ & 0.297 \\
\hline Gender & $0.92(0.68-1.24)$ & 0.583 & & \\
\hline Fuhrman grade & & $<0.001$ & & 0.020 \\
\hline (II vs. I) & $4.43(2.82-6.95)$ & $<0.001$ & $1.27(0.63-2.55)$ & 0.507 \\
\hline (III vs. I) & $9.84(6.18-15.66)$ & $<0.001$ & $1.50(0.71-3.17)$ & 0.294 \\
\hline (IV vs. I) & $21.51(12.08-38.30)$ & $<0.001$ & $2.84(1.23-6.55)$ & 0.015 \\
\hline Smoking history & $1.28(0.97-1.69)$ & 0.087 & & \\
\hline Hypertension & $1.02(0.77-1.37)$ & 0.865 & & \\
\hline Diabetes & $1.02(0.68-1.52)$ & 0.922 & & \\
\hline Tumor necrosis extent & & 0.867 & & \\
\hline $0 \%<\mathrm{TN}<20 \%$ vs. TN $=0 \%$ & $1.02(0.58-1.80)$ & 0.941 & & \\
\hline $\mathrm{TN} \geq 20 \%$ vs. $\mathrm{TN}=0 \%$ & $1.14(0.71-1.83)$ & 0.593 & & \\
\hline Ki-67 index & & 0.434 & & \\
\hline $0 \%<\mathrm{Ki}-67<10 \%$ vs. Ki- $67=0 \%$ & $1.19(0.76-1.87)$ & 0.438 & & \\
\hline Ki- $67 \geq 10 \%$ vs. Ki- $67=0 \%$ & $1.36(0.79-2.35)$ & 0.269 & & \\
\hline Tumor volume group & & $<0.001$ & & $<0.001$ \\
\hline $17 \mathrm{~cm}^{3} \leq V<40 \mathrm{~cm}^{3}$ vs. $V<17 \mathrm{~cm}^{3}$ & $2.19(1.22-3.94)$ & 0.009 & $1.93(0.95-3.91)$ & 0.069 \\
\hline $40 \mathrm{~cm}^{3} \leq \mathrm{V}<134 \mathrm{~cm}^{3}$ vs $V<17 \mathrm{~cm}^{3}$ & $6.53(4.09-10.42)$ & $<0.001$ & $5.35(2.64-10.87)$ & $<0.001$ \\
\hline$V \geq 134 \mathrm{~cm}^{3}$ vs $V<17 \mathrm{~cm}^{3}$ & $16.36(10.57-25.32)$ & $<0.001$ & $10.95(5.39-22.25)$ & $<0.001$ \\
\hline $\mathrm{BMI}(\geq 25$ vs $<25)$ & $0.92(0.68-1.24)$ & 0.579 & & \\
\hline Sugical approach (open vs laparoscopic) & $0.96(0.72-1.27)$ & 0.753 & & \\
\hline Surgical modality (partial vs radical nephrectomy) & $0.92(0.69-1.22)$ & 0.555 & & \\
\hline Tumor location (left vs right kidney) & $0.79(0.62-1.00)$ & 0.053 & & \\
\hline
\end{tabular}

Abbreviations: BMI Body mass index, HR Hazard ratio, 95\% Cl 95\% confidence interval

\section{Discussion}

RCC patients have a favorable oncological outcome after surgical treatment; however, there are still 20-30\% localized RCC patients have metastases after surgery $[5,23]$. Shah et al. found in a multi-institutional study that $5.6 \%$ of localized ccRCC patients treated with PN had disease recurrence [24]. Other studies have shown that TNM stage, Fuhrman grade, necrosis, warm ischemia time, multifocality, and bilateral occurrence of carcinoma are the most useful prognostic factors [6, 11, 12, 25]. Currently, there are no ideal prognostic factors of oncological outcomes of localized ccRCC. We assessed TV of localized ccRCC and its association with clinicopathological features and oncological outcomes.

Previous studies have suggested that the measurement of TV is applied to evaluation of renal function, but only a few report on the relationship between oncological outcomes and TV of ccRCC [17-21]. Jorns et al. [26]. concluded that TV could provide valuable prognostic information for patients with pT1a ccRCC rather than pT1b ccRCC. The researchers believed that the accuracy of TV determination using radiological imaging is of great importance for patient management. Different applications have been used to view and analyze CT crosssectional images, such as syngo Studio imaging software [17] and OncoCare CT oncology application beta software [18]. But these equations are relatively complex and not convenient for clinical application. Jorns et al. [26]. calculated TV using volume equation of ellipsoid [i.e.r/6 (length $\times$ width $\times$ height)]. However, most solid tumors are not regular spheres or ellipsoids. In this study, we introduced a more common method to calculate TV, 
Table 4 Cox regression analysis of predicting factors for freedom from local recurrence in 749 patients with localized clear cell renal cell carcinoma

\begin{tabular}{|c|c|c|c|c|}
\hline \multirow[t]{2}{*}{ Variable } & \multicolumn{2}{|l|}{ Univariate analysis } & \multicolumn{2}{|l|}{ Multivariate analysis } \\
\hline & HR $(95 \% \mathrm{Cl})$ & $P$ value & HR $(95 \% \mathrm{Cl})$ & $P$ value \\
\hline pT classification & & $<0.001$ & & 0.629 \\
\hline (T1b vs. T1a) & $5.46(1.77-16.85)$ & 0.003 & $1.10(0.25-4.83)$ & 0.965 \\
\hline (T2a vs. T1a) & $15.94(5.31-47.91)$ & $<0.001$ & $2.56(0.82-6.54)$ & 0.271 \\
\hline (T2b vs. T1a) & 43.16 (15.03-123.95) & $<0.001$ & $2.24(0.40-12.26)$ & 0.213 \\
\hline Age $(\geq 65$ vs < 65) & $0.75(0.41-1.34)$ & 0.326 & $0.74(0.39-1.32)$ & 0.258 \\
\hline Gender & $0.81(0.50-1.32)$ & 0.396 & & \\
\hline Fuhrman grade & & $<0.001$ & & 0.300 \\
\hline (II vs. I) & $7.10(2.69-18.69)$ & 0.001 & $0.89(0.28-3.43)$ & 0.137 \\
\hline (III vs. I) & $21.80(8.33-57.05)$ & 0.001 & $1.98(0.76-7.93)$ & 0.488 \\
\hline (IV vs. I) & $36.92(11.84-115.11)$ & $<0.001$ & $3.12(0.96-11.32)$ & 0.178 \\
\hline Smoking history & $1.42(0.89-2.28)$ & 0.146 & & \\
\hline Hypertension & $0.95(0.58-1.55)$ & 0.827 & & \\
\hline Diabetes & $0.91(0.45-1.83)$ & 0.782 & & \\
\hline Tumor necrosis extent & & 0.424 & & \\
\hline $0 \%<\mathrm{TN}<20 \%$ vs. TN $=0 \%$ & $1.15(0.46-2.87)$ & 0.769 & & \\
\hline $\mathrm{TN} \geq 20 \%$ vs. $\mathrm{TN}=0 \%$ & $1.60(0.79-3.23)$ & 0.193 & & \\
\hline Ki-67 index & & 0.210 & & \\
\hline $0 \%<$ Ki-67 < 10\%vs. Ki-67 =0\% & $1.79(0.94-3.44)$ & 0.078 & & \\
\hline Ki- $67 \geq 10 \%$ vs. Ki- $67=0 \%$ & $1.17(0.42-3.23)$ & 0.764 & & \\
\hline Tumor volume group & & $<0.001$ & & $<0.001$ \\
\hline $17 \mathrm{~cm}^{3} \leq V<40 \mathrm{~cm}^{3}$ vs. $V<17 \mathrm{~cm}^{3}$ & $5.10(1.47-17.71)$ & 0.010 & $4.52(1.31-15.42)$ & 0.010 \\
\hline $40 \mathrm{~cm}^{3} \leq V<134 \mathrm{~cm}^{3}$ vs $V<17 \mathrm{~cm}^{3}$ & $15.75(5.28-47.05)$ & $<0.001$ & $13.25(3.53-39.42)$ & $<0.001$ \\
\hline$V \geq 134 \mathrm{~cm}^{3}$ vs $V<17 \mathrm{~cm}^{3}$ & $44.85(15.74-127.84)$ & $<0.001$ & $32.26(12.32-117.65)$ & $<0.001$ \\
\hline $\mathrm{BMI}(\geq 25$ vs $<25)$ & $0.76(0.45-1.29)$ & 0.313 & & \\
\hline Sugical approach (open vs laparoscopic) & $0.77(0.47-1.26)$ & 0.294 & & \\
\hline Surgical modality (partial vs radical nephrectomy) & $1.12(0.70-1.79)$ & 0.650 & & \\
\hline Tumor location (left vs right kidney) & $0.81(0.51-1.31)$ & 0.061 & & \\
\hline
\end{tabular}

Abbreviations: BMI Body mass index, HR Hazard ratio, 95\% Cl 95\% confidence interval

namely, the 3D conformal radiotherapy planning system, which is widely used in the field of radiotherapy [27]. Volumetric measurements were made on enhanced CT images, in which RCCs were visualized with high resolution. This planning system is closer to the actual shape of the lesion, rather than simply overlaying the length $x$ width $\times$ height.

Pathological tumor classification (pT), Fuhrman grade and other factors have been considered as the most useful oncological outcome prognostic factors in patients with RCC [28]. TNM staging is the most important index to reflect tumor progression. It is the basis for judging the prognosis of ccRCC and making the correct treatment decisions [29]. However, Lee et al. [30] showed that $\mathrm{pT}$ classification after PN is not a significant prognostic factor of CSS, OS or RFS in patients with small renal mass. In a recent study, most pT1a tumors recurred after 5 years [31]. Remarkably, univariable Cox proportional hazards analysis showed that $\mathrm{pT}$ classification has significant association with CSS, OS and FFLR. However, multivariable analysis further demonstrated that $\mathrm{pT}$ classification was not an independent prognostic factor for CSS, OS and FFLR. We think that this result was due to the relatively high OS of patients in our study, this conclusion needs to be further verified by larger sample and multi-center study.

Fuhrman grading system is one of the most extensively used histological prognostic factors and correlates with survival [29]. Tsui et al. reported 5-year survival rates of patients with Fuhrman grade 1, 2, and 3/4 was 89, 65 and $46.1 \%$, respectively [32]. However, another study concluded that univariable analyses did not reveal that 
Table 5 Cox regression analysis of predicting factors for freedom from metastasis in 749 patients with localized clear cell renal cell carcinoma

\begin{tabular}{|c|c|c|c|c|}
\hline \multirow[t]{2}{*}{ Variable } & \multicolumn{2}{|l|}{ Univariate analysis } & \multicolumn{2}{|c|}{ Multivariate analysis } \\
\hline & HR $(95 \% \mathrm{Cl})$ & $P$ value & HR $(95 \% \mathrm{Cl})$ & $P$ value \\
\hline pT classification & & $<0.001$ & & 0.048 \\
\hline (T1b vs. T1a) & $4.10(2.16-7.78)$ & 0.001 & $2.29(0.73-7.18)$ & 0.155 \\
\hline (T2a vs. T1a) & $8.65(4.55-16.44)$ & $<0.001$ & $1.04(0.28-3.95)$ & 0.949 \\
\hline (T2b vs. T1a) & $19.22(10.39-35.57)$ & $<0.001$ & $0.71(0.16-3.12)$ & 0.651 \\
\hline Age( $\geq 65$ vs < 65) & $1.06(0.72-1.57)$ & 0.769 & $1.02(0.77-1.38)$ & 0.614 \\
\hline Gender & $0.90(0.63-1.30)$ & 0.587 & & \\
\hline Fuhrman grade & & $<0.001$ & & 0.004 \\
\hline (II vs. I) & $4.70(2.66-8.33)$ & $<0.001$ & $1.15(0.47-2.81)$ & 0.757 \\
\hline (III vs. I) & $9.70(5.35-17.57)$ & $<0.001$ & $1.52(0.58-4.01)$ & 0.398 \\
\hline (IV vs. I) & $28.03(14.11-55.69)$ & $<0.001$ & $3.76(1.32-10.74)$ & 0.013 \\
\hline Smoking history & $1.39(0.98-1.96)$ & 0.065 & & \\
\hline Hypertension & $1.10(0.77-1.57)$ & 0.609 & & \\
\hline Diabetes & $1.14(0.71-1.84)$ & 0.593 & & \\
\hline tumor necrosis extent & & 0.986 & & \\
\hline $0 \%<\mathrm{TN}<20 \%$ vs. $\mathrm{TN}=0 \%$ & $1.06(0.54-2.10)$ & 0.865 & & \\
\hline $\mathrm{TN} \geq 20 \%$ vs. $\mathrm{TN}=0 \%$ & $1.00(0.54-1.87)$ & 0.993 & & \\
\hline Ki-67 index & & 0.266 & & \\
\hline $0 \%<$ Ki- $67<10 \%$ vs. Ki- $67=0 \%$ & $0.53(0.25-1.14)$ & 0.104 & & \\
\hline Ki- $67 \geq 10 \%$ vs. Ki- $67=0 \%$ & $0.94(0.44-2.02)$ & 0.875 & & \\
\hline Tumor volume group & & $<0.001$ & & $<0.001$ \\
\hline $17 \mathrm{~cm}^{3} \leq V<40 \mathrm{~cm}^{3}$ vs. $V<17 \mathrm{~cm}^{3}$ & $2.06(0.98-4.35)$ & 0.058 & $1.00(0.33-3.08)$ & 0.999 \\
\hline $40 \mathrm{~cm}^{3} \leq V<134 \mathrm{~cm}^{3}$ vs $V<17 \mathrm{~cm}^{3}$ & $6.45(3.60-11.57)$ & 0.001 & $4.44(1.44-13.70)$ & 0.009 \\
\hline$V \geq 134 \mathrm{~cm}^{3}$ vs $V<17 \mathrm{~cm}^{3}$ & $17.07(9.91-29.42)$ & $<0.001$ & $16.16(4.27-61.10)$ & $<0.001$ \\
\hline $\mathrm{BMI}(\geq 25$ vs $<25)$ & $1.11(0.78-1.60)$ & 0.561 & & \\
\hline Sugical approach (open vs laparoscopic) & $0.99(0.70-1.41)$ & 0.970 & & \\
\hline Surgical modality (partial vs radical nephrectomy) & $1.05(0.74-1.50)$ & 0.772 & & \\
\hline Tumor location (left vs right kidney) & $0.73(0.52-1.04)$ & 0.080 & & \\
\hline
\end{tabular}

Abbreviations: BMI Body mass index, HR Hazard ratio, 95\% Cl 95\% confidence interval

Fuhrman grade is a significant mortality risk factor for nonmetastatic RCC patients [13]. In our study, survival analysis demonstrated that higher Fuhrman grade has negative association with OS, CSS, FFLR and FFM for localized ccRCC after surgery. Multivariable Cox model showed that Fuhrman grade is a prognostic factor for OS and CSS but for FFLR and FFM.

A previous study conducted by Jorns and his colleagues demonstrated that when compared with tumor diameter, RCC TV of three dimension was of greater value in predicting prognosis for $\mathrm{pT} 1 \mathrm{a}$ ccRCC patients, suggesting that RCC TV is a better indicator of actual tumor burden better than tumor diameter [26]. Meanwhile, Thiel et al. [33] evaluated 2180 patients' data and reported that the traditional way of using the largest RCC tumor diameter for staging was of poor value in predicting real TV. They proposed that new prognostic algorithms or proper staging systems should examine the use of real solid TV rather than largest tumor diameter. With the application of artificial intelligence in medical imaging, computers are becoming more and more sophisticated in identifying tumor profiles and calculating various parameters $[34,35]$. The measurement of TV is becoming easier and more accurate, which will facilitate the routine clinical measurement of TV [36].

As is known to us, this is the first report showing an association between TV and oncological outcomes of localized ccRCC. Here are some limitations of our study. Firstly, the short follow-up, retrospective, single-center characteristic and limited number of patients were the major limitations. Considering that we merely used Cutoff Finder and ROC method to identify optimal cutoff 

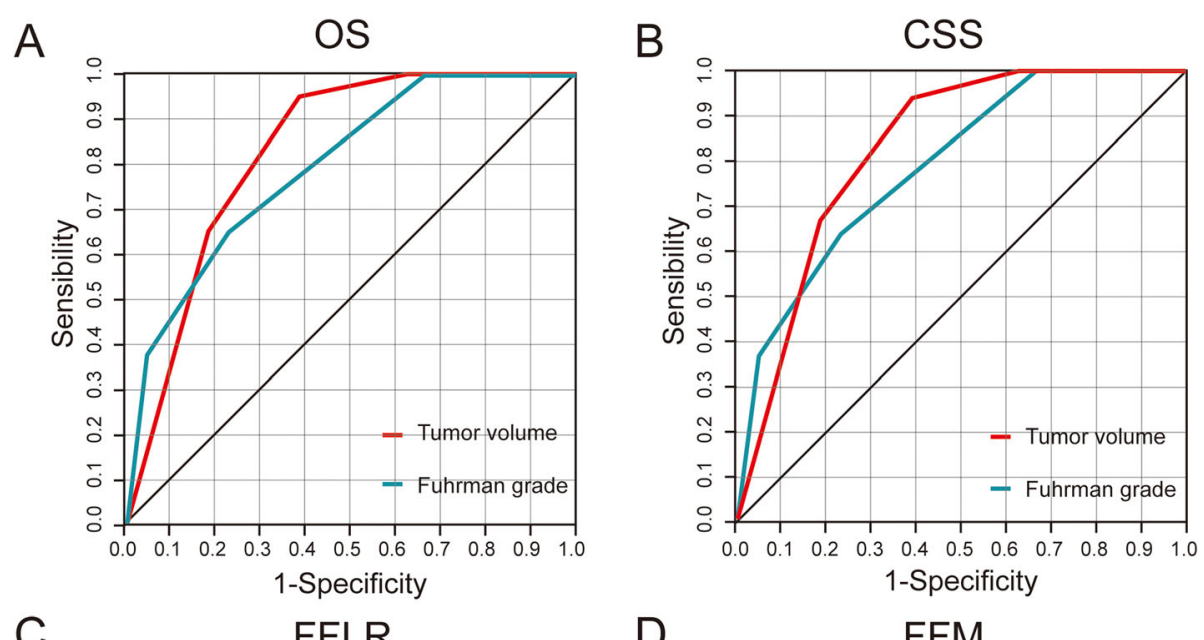

C

FFLR

D

\section{FFM}
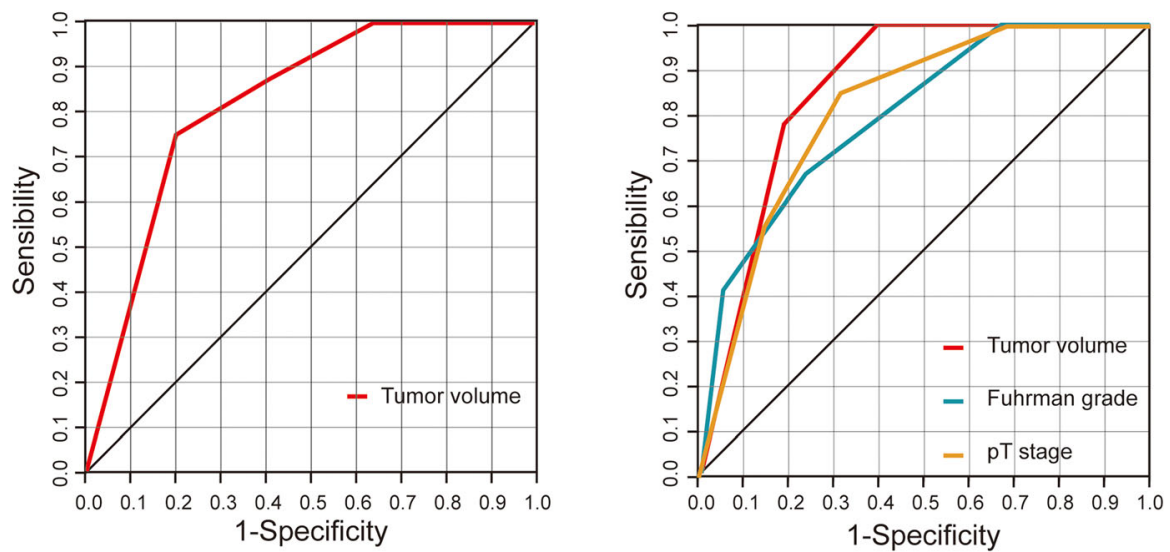

Fig. 7 a The ROC curves of in diagnosis of OS; $\mathbf{b}$ ROC curves of in diagnosis of CSS; $\mathbf{c}$ ROC curves of in diagnosis of FFLR; $\mathbf{d}$ ROC curves of in diagnosis of FFM

value without external validation, performance will be biased. Hence, the conclusions and the cutoff values require further external validation by prospective clinical studies with larger sample size and multicenter. Moreover, the number of patients with local tumor recurrence and metastasis were small. This may have affected the real relationship between Fuhrman grade, pT classification, TV and oncological outcome. Finally, we only selected patients with unifocal, unilateral pT1-2 ccRCCs, excluding metastatic and lymph node-positive patients at the time of diagnosis. Therefore, no conclusion can be drawn on pT3-4, lymph node-positive and metastatic ccRCC patients.

\section{Conclusions}

In conclusion, higher TVs were all independent prognostic factors for poorer OS, CSS, FFLR and FFM of localized ccRCC following surgery. In comparison with other prognostic factors including Fuhrman grade or $\mathrm{pT}$ classification, TV is of more value for prognostic prediction of oncological outcome of localized ccRCC. TV could be a new prognostic factor of oncological outcome of localized ccRCC, which might contribute to tailored follow-up or management strategies.

\section{Abbreviations}

3D: Three-dimensional; AUC: The area under the ROC curves; CCRCC: Clear cell renal cell carcinoma; Cl: Confidence interval; CSS: Cancer-specific survival; CT: Computed tomography; OS: Overall survival; FFM: Freedom from metastasis; FFLR: Freedom from local recurrence; $\mathrm{pT}$

classification: Pathological tumor classification; RCC: Renal cell carcinoma; ROC: Receiver operating characteristic curves; SDs: Standard deviations; TV: Tumor volume

\section{Acknowledgments}

Not applicable.

\section{Authors' contributions}

NX and QSZ made substantial contribution to the designed the study. XDL, $\mathrm{XYX}$ and $\mathrm{YW}$ have contributed to the outline and calculation of TV. FL and PH performed the statistical analyses. SHC, LYX, YPW, ZBK, XDL, XYX and YW have contributed to the acquisition of data and revision of the manuscript. SHC and LYX drafted the manuscript and all authors revised the manuscript and approved the final manuscript for publication. 


\section{Funding}

This study was supported by Fujian educational research programs for young and middle-aged teachers (Grant number: JT180187), Foundation of Fujian Provincial Department of Finance (Grant Number: 2020B017) and Guiding Project of Science and Technology Department of Fujian Province (Grant number: 2019Y0018).

\section{Availability of data and materials}

The datasets used and analyzed during the current study available from the corresponding author on reasonable request.

\section{Ethics approval and consent to participate}

This study was approved by the Ethics Committee of the First Affiliated Hospital of Fujian Medical University (No. 2015084) and written informed consent was obtained from all patients. All procedures performed in studies involving human participants were in accordance with the 1964 Helsinki declaration and its later amendments.

\section{Consent for publication}

Not Applicable. This manuscript does not contain any individual person's data in any form.

\section{Competing interests}

The authors declare that they have no competing interests.

Received: 1 May 2020 Accepted: 5 January 2021

Published online: 19 January 2021

\section{References}

1. Siegel RL, Miller KD, Jemal A. Cancer statistics, 2020. CA Cancer J Clin. 2020; 70(1):7-30.

2. Chen $Y H$, Chen SH, Hou J, Ke ZB, Wu YP, Lin TT, Wei Y, Xue XY, Zheng QS, Huang JB, et al. Identifying hub genes of clear cell renal cell carcinoma associated with the proportion of regulatory $T$ cells by weighted gene coexpression network analysis. Aging. 2019;11(21):9478-91.

3. Ljungberg B, Bensalah K, Canfield S, Dabestani S, Hofmann F, Hora M, Kuczyk MA, Lam T, Marconi L, Merseburger AS, et al. EAU guidelines on renal cell carcinoma: 2014 update. Eur Urol. 2015;67(5):913-24.

4. Chen SH, Wu YP, Li XD, Lin T, Guo QY, Chen YH, Huang JB, Wei Y, Xue XY, Zheng QS, et al. R.E.N.a.L. Nephrometry score: a preoperative risk factor predicting the Fuhrman grade of clear-cell renal carcinoma. J Cancer. 2017; 8(18):3725-32.

5. Crispen PL, Breau RH, Allmer C, Lohse CM, Cheville JC, Leibovich BC, Blute ML. Lymph node dissection at the time of radical nephrectomy for high-risk clear cell renal cell carcinoma: indications and recommendations for surgical templates. Eur Urol. 2011;59(1):18-23.

6. Kim SP, Alt AL, Weight CJ, Costello BA, Cheville JC, Lohse C, Allmer C, Leibovich BC. Independent validation of the 2010 American joint committee on Cancer TNM classification for renal cell carcinoma: results from a large, Single Institution Cohort. J Urol. 2011;185(6):2035-9.

7. Ke ZB, Chen SH, Chen YH, Wu YP, Lin F, Xue XY, Zheng QS, Xu N, Wei Y. Risk factors for brain metastases in patients with renal cell carcinoma. Biomed Res Int. 2020;2020:6836234.

8. Klatte T, Rossi SH, Stewart GD. Prognostic factors and prognostic models for renal cell carcinoma: a literature review. World J Urol. 2018;36(12):1943-52.

9. Motzer RJ, Jonasch E, Agarwal N, Bhayani S, Bro WP, Chang SS, Choueiri TK, Costello BA, Derweesh IH, Fishman M, et al. Kidney Cancer, version 2.2017, NCCN clinical practice guidelines in oncology. J Natl Compr Cancer Netw. 2017;15(6):804-34

10. Benson AB III, D'Angelica Ml, Abbott DE, et al. Hepatobiliary Cancers, Version 1.2017: Featured Updates to the NCCN Guidelines[J]. J Natl Comprehen Cancer Network. 2017:15(5):563.

11. Volpe A, Patard JJ. Prognostic factors in renal cell carcinoma. World J Urol. 2010;28(3):319-27.

12. Halachmi S, Moskovitz B, Farfara R, Nativ O. Predictors and mechanisms of oncological failure following nephron-sparing surgery for renal cancer. Isr Med Assoc J. 2011:13(3):166-71.

13. Haferkamp A, Kurosch M, Pritsch M, Hatiboglu G, Macher-Goeppinger S, Pfitzenmaier J, Pahernik S, Wagener N, Hohenfellner M. Prognostic factors influencing long-term survival of patients undergoing nephron-sparing surgery for nonmetastatic renal-cell carcinoma (RCC) with imperative indications. Ann Surg Oncol. 2010;17(2):544-51.

14. Yang B, Xia H, Xu C, Lu M, Zhang S, Wang G, Ma L. Impact of sarcomatoid differentiation and rhabdoid differentiation on prognosis for renal cell carcinoma with vena caval tumour thrombus treated surgically. BMC Urol. 2020;20(1):14.

15. Bedke J, Heide J, Ribback S, Rausch S, de Martino M, Scharpf M, Haitel A, Zimmermann U, Pechoel M, Alkhayyat $H$, et al. Microvascular and lymphovascular tumour invasion are associated with poor prognosis and metastatic spread in renal cell carcinoma: a validation study in clinical practice. BJU Int. 2018;121(1):84-92.

16. Haidar GM, Hicks TD, El-Sayed HF, Davies MG. Treatment options and outcomes for caval thrombectomy and resection for renal cell carcinoma. J Vasc SurgVenous Lymphat Dis. 2017:5(3):430-6.

17. Simmons MN, Fergany AF, Campbell SC. Effect of parenchymal volume preservation on kidney function after partial nephrectomy. J Urol. 2011; 186(2):405-10.

18. Sharma N, O'Hara J, Novick AC, Lieber M, Remer EM, Herts BR. Correlation between loss of renal function and loss of renal volume after partial nephrectomy for tumor in a solitary kidney. J Urol. 2008;179(4):1284-8.

19. Tobert CM, Boelkins B, Culver S, Mammen L, Kahnoski RJ, Lane BR. Surgeon assessment of renal preservation with partial nephrectomy provides information comparable to measurement of volume preservation with 3dimensional image analysis. J Urol. 2014;191(5):1218-24.

20. Shin TY, Komninos C, Kim DW, So KS, Bang KS, Jeong HJ, Han WK, Hong SJ, Jung BH, Lim SK, et al. A novel mathematical model to predict the severity of postoperative functional reduction before partial nephrectomy: the importance of calculating resected and ischemic volume. J Urol. 2015; 193(2):423-9.

21. Secil M, Cullu N, Aslan G, Mungan U, Uysal F, Tuna B, Yorukoglu K. The effect of tumor volume on survival in patients with renal cell carcinoma. Diagn Interv Radiol (Ankara, Turkey). 2012;18(5):480-7.

22. Budczies J, Klauschen F, Sinn BV, Gyorffy B, Schmitt WD, Darb-Esfahani S, Denkert C. Cutoff finder: a comprehensive and straightforward web application enabling rapid biomarker cutoff optimization. PLoS One. 2012; 7(12):e51862.

23. Jiang T, Wu Y-P, Chen S-H, Ke Z-B, Liang Y-C, Xu N. Prognosis and clinicopathological characteristics of renal cell carcinoma: does bilateral occurrence influence overall and cancer-specific survival? Transl Cancer Res. 2019;9(2):432-40.

24. Shah PH, Moreira DM, Okhunov Z, Patel VR, Chopra S, Razmaria AA, Alom M, George AK, Yaskiv O, Schwartz MJ, et al. Positive surgical margins increase risk of recurrence after partial nephrectomy for high risk renal tumors. J Urol. 2016;196(2):327-34

25. Fuhrman SA, Lasky LC, Limas C. Prognostic significance of morphologic parameters in renal cell carcinoma. Am J Surg Pathol. 1982;6(7):655-63.

26. Jorns J, Thiel DD, Lohse CM, Williams A, Arnold ML, Cheville JC, Leibovich BC, Parker AS. Three-dimensional tumour volume and cancer-specific survival for patients undergoing nephrectomy to treat pT1 clear-cell renal cell carcinoma. BJU Int. 2012;110(7):956-60.

27. Singh $D$, Chen $Y$, Hare MZ, Usuki KY, Zhang $H$, Lundquist $T$, Joyce $N$, Schell MC, Milano MT. Local control rates with five-fraction stereotactic body radiotherapy for oligometastatic cancer to the lung. J Thorac Dis. 2014;6(4): 369-74.

28. Rey Rey J, Leon Ramirez D, Lopez Garcia S, Fernandez Vazquez P, Benavente Delgado J, Ojea Calvo A. Pathological prognostic indicators in renal cell carcinoma. Actas Urol Esp. 2010;34(1):71-7.

29. Kucuk U, Pala EE, Sezer O, Cakir E, Bayol U, Divrik RT. Significance of TNM staging, demographic and histologic features in predicting the prognosis of renal cell carcinoma. Acta Chir Belg. 2015;115(3):202-7.

30. Lee C, You D, Yoo S, Song C, Hong B, Hong JH, Ahn H, Kim CS. Oncological outcomes of patients with incidental pathological T3a stage small renal cell carcinoma after partial nephrectomy. J Cancer Res Clin Oncol. 2016;142(7): $1651-7$.

31. van Oostenbrugge TJ, Kroeze SG, Bosch JL, van Melick HH. The blind spots in follow-up after nephrectomy or nephron-sparing surgery for localized renal cell carcinoma. World J Urol. 2015;33(6):881-7.

32. Tsui $\mathrm{KH}$, Shvarts $\mathrm{O}$, Smith RB, Figlin RA, de Kernion JB, Belldegrun $A$. Prognostic indicators for renal cell carcinoma: a multivariate analysis of 643 patients using the revised 1997 TNM staging criteria. J Urol. 2000;163(4): 1090-5 quiz 1295 
33. Thiel DD, Jorns J, Lohse CM, Cheville JC, Thompson RH, Parker AS. Maximum tumor diameter is not an accurate predictor of renal cell carcinoma tumor volume. Scand J Urol. 2013;47(6):472-5.

34. Wang S, Yang DM, Rong R, Zhan X, Fujimoto J, Liu H, Minna J, Wistuba II, Xie Y, Xiao G. Artificial Intelligence in Lung Cancer Pathology Image Analysis. Cancers. 2019;11(11):1673.

35. Goldenberg SL, Nir G, Salcudean SE. A new era: artificial intelligence and machine learning in prostate cancer. Nat Rev Urol. 2019;16(7):391-403.

36. Nazari M, Shiri I, Hajianfar G, Oveisi N, Abdollahi H, Deevband MR, Oveisi M, Zaidi H. Noninvasive Fuhrman grading of clear cell renal cell carcinoma using computed tomography radiomic features and machine learning. Radiol Med. 2020;125(8):754-62.

\section{Publisher's Note}

Springer Nature remains neutral with regard to jurisdictional claims in published maps and institutional affiliations.

Ready to submit your research? Choose BMC and benefit from:

- fast, convenient online submission

- thorough peer review by experienced researchers in your field

- rapid publication on acceptance

- support for research data, including large and complex data types

- gold Open Access which fosters wider collaboration and increased citations

- maximum visibility for your research: over $100 \mathrm{M}$ website views per year

At BMC, research is always in progress.

Learn more biomedcentral.com/submissions 